\title{
The donation and transplantation of kidneys: should the law be changed?
}

\author{
Ian Kennedy, King's College, University of London
}

\begin{abstract}
It is now eighteen years on since the Human Tissue Act 196I, but this legislation is still unchanged in England, Scotland and Wales. IanKennedy, in this paper, lays before us the law as it is, the problems of its interpretation and his opinion of what government should be doing to help clarify the situation and remove some of the problems which exist daily for the doctors who face the dilemma of seeking consent for transplants at the moment of extreme grief for the surviving spouses or relatives of the patient who has been in his care only moments before. IanKennedy suggests that by doing nothing the Department of Health and the government are being both callous and less than honest.
\end{abstract}

\section{Introduction}

Each year about 2000 people in the United Kingdom between the ages of 5 and 55 fall victim to fatal kidney disease. Most are between 15 and 35. The pain and anguish suffered by the victim, his family and friends are obviously incalculable. The cost is also immense in economic terms, including not merely the cost of medical care until death, but also the loss of productive output the victims would otherwise have contributed. What, it may be asked, is special about this? What sets it apart from other examples of fatal accident and illness ? The simple answer is that nowadays to a great extent the death is preventable. Many of the 2000 need not die.

There exist two established medical techniques for treating those with renal failure. One is the use of renal dialysis. It became an accepted form of treatment in about 1965. It involves the use of what is popularly known as a kidney machine which does the job of the diseased, non-functioning kidneys. The patient's blood is routed through the machine and the impurities which would otherwise, quite literally, poison him to death are removed. Ordinarily a patient must be attached to a machine two or three times a week for periods of eight or ten hours each time. Thus dialysis often takes place during the night while the patient sleeps. The patient need not necessarily have to attend hospital as there is a growing effort to make home dialysis available to more patients. Clearly, there are savings in terms of hospital staff and space if home dialysis can be organised. Once receiving dialysis, the patient's condition remains stable and he may continue to lead a fairly full life. The treatment is not, however, a bed of roses. It calls for considerable self-discipline in terms of diet and personal behaviour, travel and movement are obviously limited by the need to be close to the machine and nausea, discomfort and depression grow as the effects of the last treatment wane. Because of these demands, some patients are judged unsuitable for psychological reasons, for example, if they are irresponsible in matters of diet or in other relevant respects. Other patients are not recommended for dialysis for various medical reasons having to do with their physicial health. Thus, it is only a proportion of those dying of renal failure who could benefit from dialysis. The number who do in fact benefit from it is even further reduced by the chronic shortage of machines. They are of course very expensive, costing around $£ 6000$ each to which a further $£ 3000$ per machine per annum must be added to take account of training staff to use them, nursing and medical care and maintenance, and, of course, it is a long-term financial commitment.

It is a sad and some would say scandalous reality that the National Health Service has not attached the necessary priority to this demand so as to allocate all the money needed to meet the demand in full. At most, only about seven hundred people each year begin dialysis. This has forced doctors into the invidious and to them wholly unwelcome role of having to choose between patients in order to decide which one shall have dialysis, in the knowledge that a decision against a patient is a sentence of death. ${ }^{1}$ To some extent this may be a decision based on medical criteria but there is no doubt that other factors intrude, so that the question has been raised many times whether it is appropriate to leave such a decision to doctors alone.

The other form of treatment for those with renal failure has been available on a regular basis since about 1967. This is the kidney transplant. A kidney is taken from a dead person and transplanted into the donee. Less often, kidneys are taken from living donors but I shall not consider the separate, complex issues concerned with live donors here. ${ }^{2}$ If the operation is a success the patient is restored to normal good health. However, transplants should not be seen, as direct alternatives to dialysis. Often a patient must wait for some time on dialysis before transplant is available, sometimes the new kidney fails and the patient will be returned to dialysis 
possibly to await a second transplant, and for some a transplant is not an available option for medical reasons. Thus, transplantation surgery has not replaced, nor could it do without, dialysis. But, at the same time, it offers a far more attractive longterm solution in every respect, whether from the point of view of the individual patient's general health or the comparative costs involved. It is transplantation surgery and the law governing it that I shall concentrate on in this paper.

\section{The law on transplantation of kidneys}

Let me begin by mentioning that it cannot any longer be argued that kidney transplantation surgery is an experimental procedure and therefore to be considered in the light of the special legal régime governing experiments. Certainly, there is some surgery which is experimental. Indeed, heart transplants may still be regarded as such. Kidney transplants, however, have passed this point. At the same time, it should be said that the surgery itself is only part (some might say the easiest part) of the treatment. Complicated tissue-matching must be done to ensure the most favourable possible compatibility between donor and donee, elaborate procedures to ensure a sterile environment after the operation must be organised and a régime of immuno-suppressive drugs must be managed by experts who are qualified to guide the patient between the twin evils of rejection and oversusceptibility to infection. Thus, although the surgery is not experimental, it is such a demanding therapeutic process that it may only be carried out, in my view, where the procedures I have mentioned can be properly and competently undertaken. If this were not possible, to transplant a kidney would be to expose a patient to an unacceptable risk and would, in my view, attract legal liability if damage ensued. Though in the UK this is a somewhat academic point since transplantation is carried out only in designated centres, it could be important if, for example, through National Health Service cut-backs or inadequacies or whatever, such a centre was no longer able to meet the high standards required, but nonetheless continued to carry out transplants.

Turning now to the law, for obvious reasons the common law has nothing to say on the proper regulation of such a modern exercise as organ transplantation. As long ago as 1832 there was passed the Anatomy Act which regulated the use of cadavers for medical research and dissection in schools of anatomy. It thereby facilitated the training of medical students in anatomy. It did not, however, provide for the donation and subsequent removal of parts of the body for transplantation. Long after the discovery that corneas taken from the eyes of dead bodies could successfully be grafted onto the eyes of patients afflicted, for example, with intractable ulcers, Parliament belatedly passed in 1952 the Corneal Grafting Act. This was the first statute to deal directly with the transplantation of tissue. In I954 the first human kidney transplant was carried out in Massachussetts. It soon became clear that a new law dealing generally $\stackrel{9}{s}$ with transplantation was called for if such operations $\bar{O}$ were to be performed in the UK. Parliament responded in 196I with the Human Tissue Act, $\frac{\bar{D}}{5}$ repealing the Corneal Grafting Act and making $\stackrel{\mathbb{D}}{\circ}$ provision generally for the removal of tissue from cadavers for transplantation without reference to any specific tissue or organ. Despite the fact that it was passed while transplantation surgery was very much $\vec{\omega}$ in its infancy, despite the criticism levelled at it and $\sigma$ despite numerous attempts to amend or repeal it, the Human Tissue Act is still the only law there is.

\section{Criticism of the Act}

The criticisms made of the Act are basically of two kinds. The first concerns the obscurity of its $\bar{z}$ principal provisions and difficulties of meaning and interpretation. ${ }^{3}$ The second relates to the political $\stackrel{5}{5}$ and social premise upon which the Act is based; the $\vec{\varphi}$ notion that tissue should not be taken from a oै cadaver if either the deceased in his lifetime or his spouse or relatives after his death have objected to its removal. I am more concerned here to draw attention to this second criticism. Let me, in passing, point to some of the problems arising from the $\frac{\circ}{\mathbb{D}}$ language used in the Act, always remembering, of $\varrho$ course, that these problems are themselves, in part $\overrightarrow{\overrightarrow{0}}$ at least, the product of differing views as to the 3 proper scope and aim of the Act.

\section{INTERPRETATION}

It will help if $I^{-}$first set out Section $I$, subsections I and 2.

S I (I) If any person either in writing at any time or orally in the presence of two or more witnesses

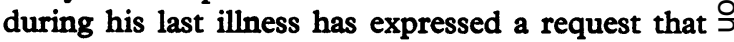
his body or any specified part of his body be used $\frac{D}{O}$ after his death for therapeutic purposes..., the person lawfully in possession of his body after his $N$ death may, unless he has reason to believe that the request was subsequently withdrawn, authorise the $O$ removal from the body of any part or, as the case may $\omega$ be, the specified part, for use in accordance with the request.

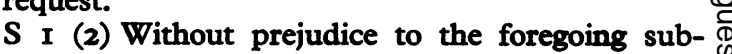
section, the person lawfully in possession of the body? of a deceased person may authorise the removal of $\frac{T}{T}$ any part from the body for use for the said purposes $\frac{O}{\mathbb{D}}$ if, having made such reasonable inquiry as may be $\bigcirc$ practicable, he has no reason to believe

a) that the deceased had expressed an objection to his body being so dealt with after his death, and had not withdrawn it: or

b) that the surviving spouse or any surviving relative

.

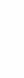

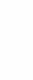


of the deceased objects to the body being so dealt with.

The first sub-section provides for what has become known as 'contracting-in', whereby the deceased may express his wish that his kidneys be used for transplanting. The second sub-section provides for the circumstance in which the deceased has not expressed any wish. It would not be an exaggeration to say that some of the words and expressions used have virtually defied all efforts at clarification. A full treatment of these problems of interpretation is inappropriate here. ${ }^{4}$ Two obvious examples are, who is 'the person lawfully in possession of the body' of the deceased and what does 'having made such reasonable enquiry as may be practicable' really amount to. There are also other problems which have bedevilled commentators, such as whether Donor Cards carried by motorists and others in fact have any legal force, on which even the Department of Health and Social Security took a contradictory stance, saying in 1973 that they did not but in 1975 that they did. For a long time too, of course, the vexed issue of the legal definition of death, crucial to the question when kidneys may be removed was a major medico-legal preoccupation, since to be of use a kidney must be removed within half-an-hour, or an hour at most, after death.

\section{THE POLICY OF THE ACT}

Once the political decision was taken that the removal of kidneys for transplantation was to be encouraged and facilitated, Parliament had to decide how to act. In particular, consideration had to be given to what opposition there was to the removal of kidneys and what (if any) weight should be given to the interests of this opposition. It is often represented that there existed for Parliament two alternatives; the policies of contracting-in, whereby kidneys are removed only from those who have requested this during their life time, and contracting-out, whereby kidneys may be removed from all except those who before death indicate their objection. In fact, a spectrum of options existed for Parliament:

I) That doctors on behalf of the National Health Service should have the right to salvage all kidneys deemed suitable, regardless of consent, objection or opposition (subject only to Coronial veto).

2) The other end of the spectrum - that kidneys be removed only if the prior consent of the deceased and his spouse and relatives has been obtained.

3) A modification of I - that kidneys be removed unless the deceased has indicated during his lifetime his objection.

4) A modification of 2 - that only the prior consent of the deceased be required.

5) A modification of 3 and 4 - that as regards 3 , the spouse and relatives should have the right to object and/or that as regards 4, that the consent of the spouse and/or relatives be required if the deceased had not objected but had not consented.

It was self-evident that the policy adopted by Parliament would have a crucial effect on the future of transplantation. If the most far-reaching scheme of contracting-out were adopted, very many kidneys would become available each year, doubtless more than the number needed. If, however, the most limited form of contracting-in, with wide scope for objections, were enacted, kidney transplantation as a viable alternative treatment would be in danger of failing for want of kidneys. The scheme which Parliament eventually adopted in the Human Tissue Act is a perfect example of political compromise. Various interests received the protection they sought. The only casualty, the committed observer may remark, is transplantation surgery itself, for there can be on doubt that, quite apart from difficulties of interpretation and other factors, the policy of the Act represents a less than energetic endorsement of transplantation.

What are the competing interests? There are at least five. First, there is the deceased, should he have a say in the disposal of his body ?; second, the spouse and relatives, should, for example, their views prevail even as against the deceased if they oppose donation while he has requested it ?; third, the potential donee, dying at an early age while the kidney which could save him is being buried or cremated; fourth, certain groups who have strongly held views on how the body of a deceased should be treated; and fifth, society at large which must bear the economic and emotional burden of 2000 people each year contracting fatal kidney disease and the cost of dialysis as an expensive alternative to transplantation, and yet must seek to respect the views of religious groups and others so as to avoid the 'tyranny of the majority.'

What Parliament decided on was a two-tier approach. First, there was S I (I), a contracting-in scheme, whereby the deceased's request, if expressed and expressed in the correct form, prevails, subject of course to the fact that it may be withdrawn and that the ultimate discretion lies with the person lawfully in possession. The second tier in SI (2) covers the circumstances in which the deceased has not made a request. In this case, Parliament seems to have opted for a contracting-out scheme, that the kidneys could be taken unless there were objections, but subject to two reservations. The first is the power of the spouse or relatives to object. The other is that Parliament, in considering on whom to place the burden of recording objection, chose to place it on the hospital authority (if it be judged the 'person lawfully in possession') rather than the relative. Thus, it becomes contracting-out with very wide limitations.

It is possible, then, to put in order the priorities respected by Parliament. First, there is the 
deceased's expressed view. Then, the spouse and relatives, in the absence of a view expressed by the deceased, have a power of veto. The existence of a veto also means that groups opposed to taking organs from the dead have succeeded in safeguarding their particular views. The dying and society at large play very much third fiddle in having their interests and needs satisfied, a rather surprising result when the stated aim of the Act in the long title was to 'make provision with respect to the use of parts of bodies of deceased persons for therapeutic purposes.'

\section{AN IRONY}

After taking so much trouble to strike what it conceived to be the right balance in the Act, Parliament then did something very strange. It failed to provide for any sanctions if the provisions of the Act were ignored! The irony is compounded in that, as I will seek to show, were it not for the policy of the Act, not to mention the difficulties of interpretation, a sufficient supply of kidneys could be obtained. So, what is to stop doctors and hospital authorities ignoring the Act which they feel bound reluctantly to observe every day? At least two reasons come to mind. ${ }^{5}$ First, it may be that a sanction does exist for non-observance, even though the reasoning required to discover it is tortuous at best. The assumption on the part of hospitals and doctors that, since it is a statute, the Act must be complied with, coupled with the fact that some sort of legal liability for non-compliance could be conjured up, persuade them to observe it, out of a sense of erring on the side of caution if nothing else. Second, whatever the law, it is probably the case that it is good, indeed required, ethical conduct to observe the Act, so that nonobservance would invite professional sanction. Notwithstanding this, it is the greatest irony that practically all those who have for so long criticised the Act and pressed for its reform have concentrated on its alleged faults and overlooked the potentially fatal flaw that it may be unenforceable.

\section{KIDNEY TRANSPLANTATION - THE REALITY}

More than 6000 people are killed in the UK each year in road accidents. From these (and I do not include the additional 2-3000 who die each year from strokes and cerebral tumour), more than enough kidneys could be salvaged for transplantation, (though of course, by no means all of these 6000 will be placed on respirators.) Of the 2000 who annually fall victim to fatal kidney failure most could benefit from a transplant. Amazingly, in 1977 in the UK only 706 transplantation operations were carried out and this figure represents a massive improvement of more than 22 per cent on the 1976 figure. In 1969 there were 200, in 1970, 274, in 1971, 315 and in 1973, 465. Why are so few transplants carried out ? Before I try to answer this, let me recall other relevant facts so that a considered judgement må be made. Renal dialysis, the alternative therapy isT very expensive, and being long-term treatment, the financial commitment is recurrent and growing. Fof? this and other reasons there has always been $\overrightarrow{F^{3}}$ chronic shortage of machines. Under the terms of the Finance Act, 1978, the Secretary of State for Health and Social Security has indicated he will allocat $£ 3^{\frac{1}{2}}$ million of the Health Service's promise additional $£ 8$ million for the purchase of 400 extra machines and for associated costs. ${ }^{6}$ This is both arp admission of the existing shortage and by all accounts a less than adequate response to it. For, on average $\frac{\overrightarrow{2}}{2}$ only 650-700 patients begin dialysis each year. Thusc్ until the new machines are in service the maximum number treated by both dialysis or transplant is approximately 1440 in 1977 . The figure for previous years has been much lower and even with the proposed new machines will only be 1800 at the very most. Thus, at present there are at least 600 peoples each year who contract kidney disease and who are told they are going to die because no treatment is్t available. This is so notwithstanding the fact that we as a society, are burying several thousand healthy kidneys each year and that a mere $f 3-5$ million ( comparatively insignificant figure in national terms would provide all the dialysis machines we needp Finally, it is not the case here, as it may be in other areas, that there is not the specialised staff available in National Health Service hospitals to deal with treatment if all were to be offered dialysis of transplantation. On the contrary, the fact is that even in these days of financial stringency in the National Health Service, not one of the 40-odd units set up throughout the country to deal with dialysis nor any of the transplant teams, is working to its full capacity. In other words, doctors are under-useop and patients are dying through lack of machines lack of kidneys and lack of political will to de? anything about it.

But, is there any link between the Human Tissue Act and the lack of kidneys? I will suggest, ing company with most commentators, that although there are other factors, the Act plays a prominen? role in bringing about this shortage. What are thes factors ? At least eight can be identified.

\section{Factors unrelated to the Act}

APATHY IN THE MEDICAL PROFESSION

Remarkably, one of the principal reasons for के shortage of kidneys is that doctors working in? hospitals, e.g. in accident units, do not appear to beo at all active in obtaining kidneys from patient $\bar{D}$ dying in their hospitals. Tam Dalyell M.P., who has campaigned vigorously for modification of the Act $\bar{D}$ pointed out in a speech to the House of Commons in December 1974 that 'many of the largest teaching hospitals, with active transplantation units, including: some of the most prestigious in Britain, have 
provided not a single kidney for transplantation.? $\mathrm{He}$ contrasted this with 'one small district general hospital, where keen, young medical staff have transplantation in mind, which provides an average of half-a-dozen donors a year'.

\section{EXTRA WORK INVOLVED}

To prepare a patient for kidney donation after death takes times and effort. A team of doctors and nurses may have spent a night and a day (or several) trying to save the patient's life and may view with something less than enthusiasm the prospect of spending another night doing all the careful work called for before the kidney can be removed.

\section{IGNORANCE OF THE SUCCESS RATE OF TRANSPLANTS}

The chances of the transplant being a success have improved markedly as tissue-typing and immunological expertise have developed and a national and international registration scheme, listing potential donees and their relevant medical histories and requirements, has been developed, so that selection of donees and donors is from a wider pool. The success rate reported in 1975 by the Committee of the British Transplantation Society in their Report was that 50 per cent of cadaver transplants were still functioning after two years and 70 per cent of the patients where transplant failed were still alive, back on dialysis and perhaps awaiting another transplant. This figure has improved somewhat since then, as it must be recalled that the operation had only been routinely performed for about five years so that data on greater life-expectancy were not then available. Also, of course, this success rate has to be judged against the background of the poor quality of the kidneys obtained. The British Transplantation Society felt these figures were very encouraging, particularly when it is recalled that a successful transplant means restoring the patient to the community as an active member. Nonetheless, it is alleged, many doctors, not directly involved in the field, are unaware of these improvements and still view transplantation as experimental, or as an alternative to dialysis which is to be avoided.

\section{ADVERSE PUBLICITY}

In 1967 heart transplants attracted massive publicity. Acclaimed at first, they were soon attacked as being, inter alia, a failure therapeutically, done for national prestige and an unjustified expenditure of scarce resources. There was also a good deal of concern about the definition of death as the press in particular ran stories of beating hearts being taken from the chests of donors. ${ }^{3}$ Whatever the validity of these arguments, there is no doubt that this bad odour affected all transplant surgery, including kidney transplant, and tended to turn public and doctors alike away from this form of surgery.

\section{Factors related to the Act}

\section{FRAMEWORK OF THE ACT}

The very framework of the Act, calling for contracting in and providing wide veto powers over contracting out limits the number of kidneys available. The number is made even smaller when account is taken of the numerous doubts and difficulties involved in its interpretation which make doctors understandably err always on the side of caution.

\section{CORONERS}

The interpretation some Coroners put on the Act further limits supply. ${ }^{3}$

THE NEED TO APPROACH THE SPOUSE OR RELATIVES If no request has been made under S.I (I) an approach has to be made to the deceased's spouse or relatives. This task falls on the doctors who have been caring for the deceased. They find it a distasteful exercise for two reasons. First, they have just lost a patient and cannot easily move on psychologically to think in terms of removing the patient's kidneys. Second, since time is of the essence, the relatives must be approached at the time when they have just heard of the death, which, even if they may have been prepared for it, will still leave them unprepared to listen to overtures concerning kidney donation and may even cause them to be resentful of what they may see as a tasteless intrusion into their grief.?

There is a rather bleak postscript to the point that the need for urgent action tends to conflict with consideration for the feelings of a spouse or relatives and the need to comply with what is seen to be the meaning of the Act. The quality of the kidneys obtained has often been poor. Problems do not arise if a donor is on a respirator as the machine can facilitate the continued supply of oxygenated blood after death. But many donors have in the past been taken off respirators, the doctor preferring the old notion of death - the absence of heart-beat - to the notion of brain-stem death. The sad and even shocking fact is that in 1975 for example as many as 17.3 per cent of all kidneys transplanted never functioned at all because, in the time taken to remove them, they had already become irretrievably damaged. The transplantation of a useless kidney which has then to be removed is, of course, doubly tragic; the patient has to undergo two useless and dangerous operations and false hopes have been raised. This makes no mention of the waste of resources in time, money and effort involved and the anguish caused to those close to the donor and donee. Indeed, so notorious did the poor quality of British cadaver kidneys become that many European transplantation centres, though linked with the UK through the European Register in Leyden for the purposes of exchange of kidneys throughout Europe, would often not, in fact, take British kidneys when they were offered for transplantation. 


\section{ADVERSE PUBLICITY}

The adverse publicity mentioned earlier may also have had the further effect of dissuading people from donating their kidneys for transplantation under S I (I).

\section{Reform of the law}

It does not necessarily follow from what has been said that the law should be changed. Some could argue that while it is accepted that not enough kidneys are becoming available under the existing statutory scheme, this is an unfortunate but inevitable price to be paid for giving proper weight to all competing interests. Others, however, would argue that if we have a law, the purpose of which is to facilitate transplantation, it makes no sense at all for hundreds to die unnecessarily each year. Of these two positions, I confess I find the second more persuasive. Thus, in this final section, I shall consider various ways in which the law may be reformed. Perhaps I should mention that the Secretary of State for Health and Social Services announced in the House of Commons in April 1978 that he intended to publish a discussion paper by the end of the year on the pros and cons of the existing law governing the donation and removal of organs. So far (January 1979) this paper has not yet appeared.

I cannot, of course, list every argument which has been put forward. I will, however, mention briefly what I consider to be the most important ones.

\section{I) Retain the existing law, with increased publicity, etc.:}

Those who argue that the existing law strikes a proper balance between the needs of the potential donee and the feelings of the deceased, his spouse and relatives urge that it should not be changed. What they propose instead is that greater advantage be taken of $S_{I}(I)$, on the basis that if it were sufficiently well-known, enough requests would be made to meet the annual need for kidneys. First, they accept and endorse the Departmental view announced by Mrs Castle that Donor Cards do meet the Act's requirements and urge a far more extensive use of them and variations on the theme of cards. For example, the proposal has been made that applications for driving licences should contain a question concerning willingness to be a kidney donor. If the applicant consented, this information could then be stored in a data bank to which hospitals could have immediate access. Another proposal has been that a tattoo could be used, put, of course, on a hidden but convenient part of the body (the inside of the lip has been suggested). Of course, the problem immediately arises of how someone once tattoed is to change his mind, quite apart from the other weaknesses of this idea, that, for example, it is painful, may be unsightly, certain people have principled objections to tattooing anc most telling, it requires rather more positive action on the part of the volunteer than is usually compatible with making such a voluntary scheme a success. In addition to these and other Donor Cara variants, it is proposed that a vigorous campaign of public education be undertaken to make peopto aware of the circumstances of kidney failure an urging them to become future donors, by writte request or whatever. However, quite apart from whether the Government would be prepared tog finance such an educational campaign, the evidence of previous such campaigns, for example, the voluntary wearing of seat belts in cars, is that the are of minimal success at most.

The plain fact is that these proposals are wel $\overrightarrow{\mathbb{R}}$ meaning but most unlikely to have any real effect. Only a very few will be persuaded to volunteer. It if a sad fact that transplant surgeons will report with hint of irony that it is very rare indeed that peop who carry Donor Cards actually become donors. By their nature they are public-spirited and cons scientious people and less likely, therefore, become the victims of road accidents and other traumas. The prime candidate, the young, healthi motor-cyclist, who by his youth and choice of transport is clearly convinced of his immortalit will be just the person not to have volunteered as future donor.

\section{2) Amend the Act}

The most recent and well-known examination क्ष kidney donation was a Report published in 1975 by Committee of the British Transplantation Societ? called 'The Shortage of Organs for Clinical Trans plantation.' 4 A number of recommendations were made. The principal proposal, and one echoed big others, was for the Act to be amended in particula details. The aim appears to have been two-fold; first, to retain the underlying policy of the Act, i. contracting-in, S I (I), contracting-out with limitations, S I (2), while, secondly, so to redrat these two subsections as to remove existing uncer tainites, thereby facilitating a greater supply $\stackrel{\text { \&f }}{ }$ kidneys. In particular, a new form for $S$ I (2) walo proposed, and an interpretation section for $S_{I}$ (I) and (2). In the proposed interpretation section it 8 made explicit that the hospital authority is the person lawfully in possession of a body lying in hospital, at least until such a time as someone with a greater claim demands it. It also provides that printed Donor Cards or other such documents are 'in writing' for the purpose of S I (I).

The revision of $S_{I}(2)$ is crucial. It concerns itse with the question of what inquiry must be made and proposes the following version:

Without prejudice to the foregoing sub-section, the person lawfully in possession of the body of deceased person may authorise the removal of any 
part from the body for use for the said purposes if, having made such inquiry as is both reasonable and practicable in the time available, he has no reason to believe that the deceased had expressed an objection (which he was not known to have withdrawn) to his body being so dealt with after his death.

Provided that authorisation shall not be given under this subsection if the person lawfully in possession of the body has reason to believe that the surviving spouse or any surviving relative of the deceased objects to the body being so dealt with.

The Committee note that only 'in one respect' is any change made in the existing law: that, by the new $S$ I (2), the person lawfully in possession 'would no longer be under a duty to make enquires' as to whether a spouse or relative objected to removal. For, the proviso to the proposed S I (2) merely refers to having reason to believe without the requirement of an obligation to enquire. This has to be understood, however, in the light of the proposed definition of 'the time available' in the interpretation section, as meaning only that period of time 'until the moment at which steps must be taken to remove the part of the body, if it is to be suitable for the therapeutic ... purpose'. It is my view that the Committee somewhat understates the significance of their proposal. It may alter the law only in one respect, but, on one reading of the proposal, that respect involves a virtual abandonment of the central thesis of the Act (which the Committee claims to accept), the spouse's or relatives' power of veto. For, if it is conceded that, optimally, kidneys should be removed as soon as death is pronounced, 'the time available' may, by reference to the interpretation section, be made to mean a mere matter of seconds or minutes. Given that no obligation is cast upon the hospital authority to discover objections, unless a spouse or relative is both aware that death is imminent and is on the spot when it takes place, he may be presented with a fait accompli; that the kidney has been removed. Admittedly, the Committee argue that the doctor would 'invariably approach the closest available relatives', but he is not required to do so. Thus, the Committee's recommendations are far from satisfactory, in that they either provide for one course of conduct while recommending another, thereby writing uncertainty back into the Act, or they provide for a radical shift of policy towards what is capable of being almost a full-scale contracting out scheme, though masquerading as maintaining the existing policy. If the Committee had thought contracting-out, though the right approach, was politically unlikely to be adopted, then they should, perhaps, have said so and confronted the issue more openly.

\section{3) The sale of kidneys}

If cadaver kidneys are not available in sufficient numbers, one radical way to make up the deficiency, which would respect all existing objections against removing them from the dead, would be to allow the living to sell one of their kidneys. ${ }^{8}$ Nature provides us with two kidneys but we can live perfectly well with one. Why should not someone be able to sell the other? Such a proposal is hardly voiced in Britain and when it is, the response is prompt and hostile. Yet in the USA the sale of kidneys and other organs has been much discussed and is not unknown. There are several interconnecting levels on which to consider this issue. The first is the purely legal one. Would such a sale be considered valid and enforceable, or be judged to be contrary to public policy? Would the whole apparatus of products liability and exemption clauses surround such sales? The possible answers to these questions lead to deeper philosophical issues, such as whether we as a society think it right to condone a traffic in human parts or regard it as fundamentally degrading, or, put another way, whether a society acting paternalistically should deny an individual his right to self-determination, to do with himself as he pleases, to engage in unorthodox but perhaps profitable commerce, when the exercise of such a right involves a mutilating operation. Further, should a society committed to a National Health Service contemplate the possibility that kidneys become available only to the highest bidder, leaving the poor to die? Then there are medical-ethical issues, such as whether the person's consent to the removal of his kidney for sale is real, or one induced by financial need or other stress. Also the history of the sale of blood in the USA may caution us against supporting the notion of selling kidneys. As Titmuss pointed out in his classic study, ${ }^{10}$ blood donors in the USA who sell their blood, more often than not are poor and often unhealthy. Their medical histories, which would be even more critical in the case of kidneys, may be fabricated so to suppress unfavourable facts and thus ensure they are not refused as donors. Finally, and this could be the most crucial objection if kidneys were involved, testing procedures may not be carried out with all the proper rigour. For, the doctor removing the blood is often a middle-man, reselling his product, and the greater desire for profit, the less inclined he is to reject the donor.

There are, of course, counter-arguments. Some see nothing wrong with the market place playing its part here as elsewhere. They need not take the more extreme position widely held in the USA that health care is a commodity, to be brought and paid for, rather than a service available to all, rich and poor alike. Instead, they can argue that those who can afford it should pay, always assuming there are sellers, and those who cannot should have the kidneys which have been donated under the existing law. Further, they can point to psychological arguments which have it that there is gratification in 
the donee and an enhanced feeling of well-being, rather than possible guilt at having taken something from the dead, or at having been given a kidney while others have been allowed to die. They may argue also that any method of increasing the supply of kidneys is to be welcomed in the light of the existing state of affairs. Finally, the point can be made that if the idea of cash for kidneys is deemed too objectionable, there are, of course, other methods of payment. It can take the form of future priority treatment for the donor and/or relatives in case of illness, or some form of indemnity insurance against future illness.

These are some of the arguments. They are rarely aired. I must say I am firmly opposed to the sale of kidneys and think it most unlikely that such sales would be tolerated here in the UK. Some indeed go so far as to propose they be outlawed, as does, for example, the recent 1977 Report of the Australian Law Reform Commission on Human Tissue Transplants. ${ }^{11} \mathrm{I}$ am inclined to think such legislation is unnecessary.

\section{4) Contracting-out}

As was seen at the outset, a spectrum of choices was and is available to Parliament as to whose interest should weigh most heavily in any law governing transplants. In the light of the past ten or so years of kidney transplantation, it can be concluded that the present mixture of voluntary contracting-in and contracting-out subject to veto has weighted the scales heavily against those dying of kidney failure. Partial reforms such as giving the spouse or relatives less power may be the answer. Indeed, the Australian Report, after some equivocating, opts for this. My view is that if we really care about helping those afflicted by kidney disease, who it will be recalled are often young people and have so much to offer, then piecemeal, bitty reforms should be seen for the partial solutions they are and abandoned. Instead, Parliament should take the positive step of introducing a pure contracting-out system. Even this does not go far enough for some, since it gives the deceased a power of veto, by registering his objection before death, whereas they would advocate removal regardless of anyone's wishes. Donald Longmore put it strikingly, as follows: 'We can either preserve the ancient laws that guarantee the inviolability of the dead, and the present rights of the next-of-kin, or we can rewrite those laws in favour of the living' ${ }^{12}$

That Parliament has not introduced contractingout despite considerable pressure over ten years should suggest that powerful arguments exist against it. But, it is not clear what these arguments are. Nonetheless, the past ten years show a record of complete failure of any attempt to change the law. In I968 Sir Gerald Nabarro introduced a Bill providing for the removal of kidneys unless the deceased had during his life indicated his opposition. The Bill failed in 1968 and again in 1969, the
Government of the day opposing it on the rathê spurious ground that it dealt only with kidneys whereas any law should deal generally with af transplants. In 1969 the Government's own Advisory Group ${ }^{13}$ set up to consider the working of the Act recommended, albeit by a bare majorit: contracting-out but its views were completefy ignored. It is true that a British Medical Association Committee in 1970 advised against contracting-o 6 ot but, in part, their opposition was the product of $\frac{0}{2}$ general antipathy to transplantation at the time, created by the failures of various heart transplants, which, of course, had nothing to do with kidney transplants. The Bar Council in its Report ${ }^{14}$ r97I was also against contracting-out, principaly as it invaded the rights of the individual, but thos is patently question-begging, as it depends on which individual is considered, the deceased, his spouse or relative, or the dying patient. On ninfe occasions culminating in his Transplantation of Organs Bill in 1974, Tam Dalyell, MP, has sought to introduce the system of contracting-out, eagt time to be met with no support from the Goverpment. Finally, the Report of the British Transplantation Society ${ }^{4}$ I referred to earlier certainfy edges towards contracting out but failed to provoke any response from the Government, despite the distinction of the members who wrote it.

I ask again, why have successive Governments not changed one word of the I96I Act ? I can firfid no satisfactory answer save the exertion of pressufe by those who claim they are safeguarding freedorif; and a wholly unjustified timouressness on the past of the Department of Health and Social Security concerning public opposition, which, if the views of those involved in the area are to be trusted, is completely unfounded, since the consensus off informed opinion is that the vast majority of the public do not share the misgivings attributed them by the Government and Parliament.

Mahoney, ${ }^{15}$ in a careful examination of con tracting-out, presents a number of ethical oBjections. He reaches the conclusion that voluntany service is better in such matters than conscription because of what it says about the society and the respect given to differing viewpoints. Voluntary donation, he says, may be less efficient but is mot humane. Again, the question is begged, since imagine that Mahoney would also at the same tine deny that it is humane to stand by and let hundreds of people die each year, when their lives could saved.

Certainly, there can be no argument against contracting-out based on cost, as it is obvious that as between dialysis and transplant, the latter $\mathbb{B}_{8}$ much cheaper. Finally, there is no lack of examples in other countries of contracting-out laws. France, Czechoslovakia, Hungary, Sweden, Norway and Israel all have contracting-out. ${ }^{16}$ Indeed, whise somewhat perversely recommending a scheme like 
the Human Tissue Act, the Australian Report inclined to the view that contracting-out would be the accepted model within five years.

If the Department of Health and Social Security does not in its proposed consultation document, offer a reasoned and compelling argument against contracting-out, the Government should, in my view, be obliged to introduce it as soon as possible. Furthermore, if the Department, with or without reasons, opposes contracting-out, it must quite clearly face the fact that it is condemning many suffering from kidney failure to die for want of resources, given that an adequate number of dialysis machines is not available. Also, given that resources are, as a matter of policy, being restricted, the Department must suggest criteria according to which these scarce resources should be made available. To leave these harrowing decisions to doctors is grossly unfair. Of course, the Department would not dream of entering that particular lion's den. But, in failing to lay down guidelines, while condoning, through inaction, the circumstances which demand them, the Department and the Government are both callous and less than honest.

\section{Acknowledgments}

The writer wishes to acknowledge gratefully the information and analysis contained in the works listed as suggested reading on which he has leaned heavily.

The editor of this fournal wishes to thank the publishers of The Bracton Law Fournal (Exeter University Law Faculty) for their kind permission to republish the above article in this slightly abridged form.

\section{References and notes}

'See for example the very recent report from Office of Health Economics (1978), Renal failure: a priority in health and the comment thereon in The Times, I5 March 1978.

${ }^{2}$ The Australian Law Reform Commission Report No. 7 (1977), Human Tissue Transplants, Chapter 9.

${ }^{3} \mathrm{~K} e n n e d y$, Ian (1969). Alive or dead: the lawyer's view. Current Legal Problems, 22, 102.

'For a thorough discussion see Lanham (1971). Transplant and the Human Tissue Act $196 \mathrm{I}$ in Medicine, Science and the Law, 11, I6 and Dworkin (1970). The law relating to organ transplantation in England in Modern Law Review, 33, 353 and
British Transplanation Society (1975). The Shortage of Organs for Clinical Transplantation in British Medical fournal, I, 25 I.

${ }^{5}$ Skegg (1974). Liability for the unauthorised removal of cadaveric transplant material in Medicine, Science and the Law, 14, 53 and Kennedy, Ian (1976). Further thoughts on liability for non-observance of the provisions of the Human Tissue Act 196I in Medicine, Science and the Law, 16, 49.

${ }^{6}$ The Times (1978), April 6.

${ }^{7}$ Calne, R Y et al (1975). Transplantation. Fournal of Medical Ethics, r, 2, p 6r.

${ }^{8}$ See the full discussion Australian Law Reform Commission Report, op. cit., Chapter 15.

'Dukeminier (1970). Supplying organs for transplantation in Michigan Law Review, 68, 812.

${ }^{10}$ Titmuss (1970). The Gift Relationship, London: George Allen and Unwin. See also Plant, Raymond (1977 and 1978). Gifts, exchanges and the political economy of health care, Parts I and 2 in fournal of Medical Ethics, 3, 4, pp 166-173 and 4, I, pp 5-II.

${ }^{11}$ Australian Law Reform Commission Report, op. cit., 187.

${ }^{12}$ Longmore, D (1968), Spare Part Surgery. London, Aldons Books.

${ }^{13}$ Advice from the Advisory Group on Transplantation Problems on the question of Amending the Human Tissue Act 196I (1969). London. Her Majesty's Stationery Office.

${ }^{14}$ Report of a Law Reform Committee on the Law relating to Organ Transplantation, adopted by the Bar Council (I97I), July 20.

${ }^{15}$ Mahoney, John (I975). Ethical aspects of donor consent in transplantation. Fournal of Medical Ethics, I, 2, pp 67-70.

${ }^{16}$ Australian Law Reform Commission Report, op. cit. Chapters 7 and ro.

\section{Suggested reading}

For a comprehensive survey of the area covered in this paper the following are recommended:

The Australian Law Reform Commission Report No. 7 (1977). Human Tissue Transplants.

British Transplantation Society (1975). The shortage of organs for clinical transplantation, British Medical fournal, $x, 25 \mathrm{I}$.

Calne, R Y et al (1975). Transplantation, fournal of Medical Ethics, I, I pp 59-72.

Jones and Bodmer (1974). Our Future Inheritance, Oxford University Press, Chapter 5.

Lanham (1971). Transplant and the Human Tissue Act 1961, Medicine, Science and the Law, 11, I6.

Ethics in Medical Progress (1966), Churchill, Ciba Foundation. 